\title{
A Review of the Monitoring \& Diagnostic Methods of Oil Immersed Transformers
}

\author{
Remya Krishnan* \\ Design Engineer \\ Federal Transformers Co. LLC, \\ Abu Dhabi, UAE.
}

\begin{abstract}
Transformer is vital equipment in a power system and to ensure reliable service and to plan for timely preventive maintenance suitable monitoring \& diagnostic methods are required. This paper gives a review of the on-line monitoring \& diagnostic and off-line diagnostic methods used for oil immersed transformers.
\end{abstract}

Keywords-Distribution Transformer; Dissolved gas Analysis (DGA); Furan analysis; Degree of polymerization of transformers; Sweep frequency response analysis

\section{INTRODUCTION}

The modern power system is mandated to provide reliable uninterrupted power supply and therefore, it is important to ensure the health and longevity of the transformer. There are several effective on-line and off-line diagnostic tools available today for the diagnostic the condition of the transformer which can identify incipient faults, estimate the remaining life, and ascertain maintenance strategy or to schedule the retirement \& replacement of the transformer. This paper lists out the diagnostic / monitoring methods and reviews some of the commonly used techniques.

\section{ON-LINE AN OFF-LINE DIGNOSTIC METHODS}

The online monitoring / diagnostic methods measure the inputs continuously without affecting the operation of the transformer whereas the off-line methods need the planned shutdown of the transformer. Maintaining the Integrity of the Specifications

\section{I. $\quad$ On Line monitoring}

Table I shows the commonly used on line data monitoring methods. The measurement applicable for a particular transformer is selected based on the design, the application, the rating etc.

\begin{tabular}{|c|c|l|}
\multicolumn{3}{c|}{ TABLE I ON-LINE MONITORING METHODS } \\
\hline Sl. & Transformer & \multicolumn{1}{c|}{ On Line Data Monitored } \\
No. & Subsystem & \\
\hline 1. & Core \& Coil & - Load current of Transformer \\
& Assembly & -Terminal Voltage of \\
& & Transformer \\
& & -Winding Temperature \\
& & -Top oil Temperature \\
& & -Peak Voltage of surge (if any) \\
& & -Short circuit current / surge \\
& & current (if any) \\
& & -Search coil based monitoring \\
& & of internal faults \\
& & -Dissolved gases in oil (DGA) \\
& & -Core to ground current \\
& & -Tank to ground current \\
& & -Moisture in oil \\
\hline
\end{tabular}

Dr. K.R. M. Nair

Chief Operating Officer

Federal Transformers Co. LLC, Abu Dhabi, UAE.

\begin{tabular}{|c|c|c|}
\hline & & $\begin{array}{l}\text {-Operating Noise } \\
\text {-Partial discharge measurement }\end{array}$ \\
\hline 2. & $\begin{array}{c}\text { Oil Preservation } \\
\text { System }\end{array}$ & $\begin{array}{l}\text { - Oil level in Tank/conservator } \\
\text {-Nitrogen / gas pressure level } \\
\text {-Moisture in oil }\end{array}$ \\
\hline 3. & Cooling System & $\begin{array}{l}\text {-Ambient Temperature } \\
\text {-Cooling system supply } \\
\text {-Cooling fan status (ON/OFF) } \\
\text {-Fan motor current } \\
\text {-Status of oil pump (ON/OFF) } \\
\text {-Oil pump motor current } \\
\text {-Oil flow through the pump }\end{array}$ \\
\hline 4. & Bushings & $\begin{array}{l}\text {-Capacitance \& Tan delta } \\
\text {-Leakage current } \\
\text {-Bushing voltage through } \\
\text { capacitive coupler }\end{array}$ \\
\hline 5. & $\begin{array}{l}\text { On Load Tap } \\
\text { Changer }\end{array}$ & $\begin{array}{l}\text {-OLTC oil level } \\
\text {-Dissolved gas in OLTC oil } \\
\text {-Moisture content in OLTC oil } \\
\text {-Current through OLTC } \\
\text { (winding current) } \\
\text {-Oil temperature of OLTC } \\
\text { Diverter switch }\end{array}$ \\
\hline
\end{tabular}

\section{Off-Line Diagnostic Methods}

Off-line measurements are taken when a transformer is disconnected from service. The major techniques are given below. Most of the on-line monitoring parameters in 2.1 can be measured and analyzed off-line also, depending on the criticality of the installation and the type of diagnostic system envisaged.

- Insulation resistance and polarization index

- $\quad$ Capacitance \& Tan delta measurement

- Oil break down voltage

- $\quad$ Polarization, Depolarization current (PDC)

- $\quad$ Recovery voltage method

- Optical spectroscopy

- $\quad$ Sweep Frequency Response Analysis (SFRA)

- Dielectric Frequency Response Analysis (DFRA)

- $\quad$ Impulse Frequency Response Analysis

- Transformer Impedance circle characteristics

- $\quad$ Frequency Domain Spectroscopy

\section{MAJOR MONITORING AND FAULT DETECTION} DIAGNOSTIC METHODS

The predictive maintenance and reliability centered techniques used frequently are reviewed here. 


\section{A. Dissolved Gas Analysis}

Dissolved Gas Analysis (DGA) detects incipient fault conditions leading to future faults of transformer. Oil is a hydrocarbon molecule containing hydrogen and carbon atoms forming chemical bonds. Decomposition of Electrical insulation materials in transformer (paper \& oil) generates gases. Table II, shows the various gases developed in the transformer oil.

TABLE II VARIOUS GASES DISSOLVED IN THE TRANSFORMER OIL

\begin{tabular}{|c|c|c|c|}
\hline Gas & Formula & $\begin{array}{l}\text { Temperature at } \\
\text { which gas forms }\end{array}$ & Source of Gases \\
\hline Hydrogen & $\mathrm{H}_{2}$ & $\begin{array}{l}<150^{\circ} \mathrm{C}-\text { Corona } \\
\text { in oil } \\
>250^{\circ} \mathrm{C}-\text { Thermal } \\
\& \text { Electrical faults }\end{array}$ & $\begin{array}{l}\text { Partial } \\
\text { Discharge } \\
\text { Thermal faults } \\
\text { Power } \\
\text { Discharges }\end{array}$ \\
\hline Methane & $\mathrm{CH}_{4}$ & $<150^{\circ} \mathrm{C}-300^{\circ} \mathrm{C}$ & $\begin{array}{l}\text { Corona partial } \\
\text { discharge low \& } \\
\text { medium } \\
\text { temperature } \\
\text { faults }\end{array}$ \\
\hline Ethane & $\mathrm{C}_{2} \mathrm{H}_{6}$ & $200^{\circ} \mathrm{C}-400^{\circ} \mathrm{C}$ & $\begin{array}{l}\text { Low and } \\
\text { medium } \\
\text { temperature } \\
\text { faults }\end{array}$ \\
\hline Ethylene & $\mathrm{C}_{2} \mathrm{H}_{4}$ & $300^{\circ} \mathrm{C}-700^{\circ} \mathrm{C}$ & $\begin{array}{l}\text { High } \\
\text { temperature } \\
\text { Thermal faults }\end{array}$ \\
\hline Acetylene & $\mathrm{C}_{2} \mathrm{H}_{2}$ & $>700^{\circ} \mathrm{C}$ & $\begin{array}{l}\text { High Hot Spot. } \\
\text { Low Energy } \\
\text { discharge. }\end{array}$ \\
\hline $\begin{array}{l}\text { Carbon } \\
\text { Monoxide }\end{array}$ & $\mathrm{CO}$ & $\begin{array}{l}105^{\circ} \mathrm{C}-300^{\circ} \mathrm{C} \\
>300^{\circ} \mathrm{C} \text { complete } \\
\text { decomposition }\end{array}$ & $\begin{array}{l}\text { Thermal faults } \\
\text { involving paper } \\
\text { press board, } \\
\text { wood etc. }\end{array}$ \\
\hline $\begin{array}{l}\text { Carbon } \\
\text { Dioxide }\end{array}$ & $\mathrm{CO}_{2}$ & $100 \mathrm{oC}-300 \mathrm{oC}$ & $\begin{array}{l}\text { Normal aging } \\
\text { Thermal fault } \\
\text { involving } \\
\text { cellulose }\end{array}$ \\
\hline Oxygen & $\mathrm{O}_{2}$ & $\begin{array}{l}\text { Vacuum when } \\
\text { temperature drops }\end{array}$ & $\begin{array}{l}\text { Exposure to air, } \\
\text { Leaky gasket } \\
\text { Air breathing } \\
\text { through } \\
\text { Conservator }\end{array}$ \\
\hline
\end{tabular}

Gases dissolved in oil are analyzed by gas chromatography which separates each gas form other and directly measures their concentrations individually. The interpretation is carried out by the guidelines given in IEC 60599-2007-5 "mineral oil Impregnated Electrical Equipment in service: guide to the interpretation of Dissolved and Free gas Analysis" or IEEE C57.104.2008 - "IEEE guide for the Interpretation of gases generated in Oil Immersed Transformer". or CIGRE guidelines or Dual triangle or a combination.

The concentration of various gases and the ratios of the concentration give conclusion regarding the type of fault/condition existing in the transformer.

TABLE III IEC 60 599-2007-5 METHOD

\begin{tabular}{|c|c|c|c|}
\hline $\mathrm{C}_{2} \mathrm{H}_{2} / \mathrm{C}_{2} \mathrm{H}_{4}$ & $\begin{array}{c}\mathrm{CH}_{4} / \\
\mathrm{H}_{2}\end{array}$ & $\begin{array}{c}\mathrm{C}_{2} \mathrm{H}_{4} / \\
\mathrm{C}_{2} \mathrm{H}_{6}\end{array}$ & Fault Type \\
\hline Not significant & $<0.1$ & $<0.2$ & Partial Discharge \\
\hline$>1.0$ & $0.1-$ & $>1.0$ & $\begin{array}{c}\text { Discharge of } \\
\text { Low Energy }\left(\mathrm{D}_{1}\right)\end{array}$ \\
\hline $0.6-2.5$ & $0.1-$ & $>2.0$ & $\begin{array}{c}\text { Discharge of } \\
\text { High Energy }\left(\mathrm{D}_{2}\right)\end{array}$ \\
\hline
\end{tabular}

\begin{tabular}{|c|c|c|c|}
\hline Not Significant & $>1.0$ & $<1.0$ & $\begin{array}{c}\text { Thermal Fault }< \\
300^{\circ} \mathrm{C}\end{array}$ \\
\hline$<0.1$ & $>1.0$ & $1.0-4.0$ & $\begin{array}{c}\text { Thermal Fault } \\
<300^{\circ} \mathrm{C} \text { to } 200^{\circ} \mathrm{C} \\
\left(\mathrm{T}_{2}\right)\end{array}$ \\
\hline$<0.2$ & $>1.0$ & $>4.0$ & $\begin{array}{c}\text { Thermal Fault }> \\
700^{\circ} \mathrm{C}\left(\mathrm{T}_{\mathrm{s}}\right)\end{array}$ \\
\hline
\end{tabular}

When the values of $\mathrm{CO}>500 \mathrm{PPM}$ and $\mathrm{Co}_{2}>5000 \mathrm{PPM}$ $\mathrm{CO}_{2} / \mathrm{CO}$ Ratio of $<3$ indicates thermal cellulosic Degradation. (However, this ratio is not reliable for sealed type Transformers). A ratio 3 to 11 is considered healthy cellulose insulation.

- Interpretation by CIGRE SC15

The guidelines for interpretation of DGA in oil filled transformers as per CIGRE SC-15 is given in Table IV

\begin{tabular}{|c|c|c|c|}
\hline Name & Ratio & Significant Value & $\begin{array}{c}\text { Interpretati } \\
\text { on }\end{array}$ \\
\hline Key Ratio 1 & $\begin{array}{c}\mathrm{C}_{2} \mathrm{H}_{2} / \\
\mathrm{C}_{2} \mathrm{H}_{6}\end{array}$ & $>1$ & Discharge \\
\hline Key Ratio 2 & $\mathrm{H}_{2} / \mathrm{CH}_{4}$ & $>10$ & $\begin{array}{c}\text { Partial } \\
\text { Discharge }\end{array}$ \\
\hline Key Ratio 3 & $\begin{array}{c}\mathrm{C}_{2} \mathrm{H}_{4} / \\
\mathrm{C}_{2} \mathrm{H}_{6} \\
\end{array}$ & $>1$ & $\begin{array}{l}\text { Thermal } \\
\text { fault in oil }\end{array}$ \\
\hline Key Ratio 4 & $\mathrm{CO}_{2} / \mathrm{CO}$ & $\begin{array}{c}>10 \text { indicate over } \\
\text { heating of cellulose } \\
<3 \text { indicates } \\
\text { degradation of } \\
\text { cellulose by } \\
\text { Electrical }\end{array}$ & $\begin{array}{c}\text { Cellulose } \\
\text { Degradatio } \\
n\end{array}$ \\
\hline Key Ratio 5 & $\mathrm{C}_{2} \mathrm{H}_{2} / \mathrm{H}_{2}$ & $\begin{array}{c}>2(>30 \text { PPM }) \\
\text { Diffusion from } \\
\text { OLTC or through } \\
\text { common } \\
\text { conservator }\end{array}$ & $\begin{array}{c}\text { Applicable } \\
\text { for in Tank } \\
\text { OLTC }\end{array}$ \\
\hline
\end{tabular}

Evaluation of Faults by Rogers Ratio Method (IEEE C57.104.2008) Table VI gives the 6 different cases as per IEEE C57.104.2008

TABLE V DIFFERENT CASES AS PER IEEE C57.104.2008

\begin{tabular}{|c|c|c|c|c|}
\hline Case & $\begin{array}{c}\mathrm{R}_{1} \\
\mathrm{CH}_{4} / \mathrm{H}_{2}\end{array}$ & $\begin{array}{c}\mathrm{R}_{2} \\
\mathrm{C}_{2} \mathrm{H}_{2} / \\
\mathrm{C}_{2} \mathrm{H}_{4}\end{array}$ & $\begin{array}{c}\mathrm{R}_{3} \\
\mathrm{C}_{2} \mathrm{H}_{4} / \\
\mathrm{C}_{2} \mathrm{H}_{6}\end{array}$ & Diagnosis \\
\hline 0 & $\begin{array}{c}>0.1 \text { to } \\
1.0\end{array}$ & $<0.1$ & $<1.0$ & Normal unit \\
\hline 1 & $<0.1$ & $<0.1$ & $<1.0$ & $\begin{array}{c}\text { Low Energy Arcing } \\
-\mathrm{PD}\end{array}$ \\
\hline 2 & $\begin{array}{c}0.1 \text { to } \\
1.0\end{array}$ & $\begin{array}{c}0.1 \text { to } \\
3.0\end{array}$ & $>3$ & $\begin{array}{c}\text { Arcing }- \text { High } \\
\text { Energy Discharge }\end{array}$ \\
\hline 3 & $\begin{array}{c}>0.1 \text { to } \\
<1.0\end{array}$ & $<0.1$ & 1.0 to & $\begin{array}{c}\text { Low Temperature } \\
\text { Thermal }\end{array}$ \\
\hline 4 & $>1.0$ & $<0.1$ & 1.0 to & Thermal $<700^{\circ} \mathrm{C}$ \\
\hline 5 & $>1.0$ & $<0.1$ & $>3.0$ & Thermal $<700^{\circ} \mathrm{C}$ \\
\hline
\end{tabular}

- Duval Triangle

Duval Triangle method plots the relative percentage of $\mathrm{CH}_{4}$, $\mathrm{C}_{2} \mathrm{H}_{4}$ and $\mathrm{C}_{2} \mathrm{H}_{2}$ on each side of a triangle from 0 to $100 \%$. 6 zones of faults are indicated in the triangle and a zone indicating mixture of thermal and Electrical faults (DT zone) This graphical method follows the evolution of faults with time. Several software packages are available for DGA interpretations using triangle method. In an oil filled transformer the dielectric including cellulose and oil is continuously under electrical stress. The minor voids or 
imperfections, conductive particles etc create localized stresses leading to partial breakdown of the dielectric. These discharges are very fast electrical processes and radiate electromagnetic waves of high frequency and ultra High frequency range. If such partial discharges are continuously increasing, it is a sure sign of a weak insulation, high stress concentration etc. These are signs of incipient faults.

A healthy oil filled transformer can have PD magnitude of 10$50 \mathrm{PC}$ or lower at operating voltage. The increasing PD levels signify the following:

\section{TABLE VI SIGNIFICANCE OF VARYING PD LEVELS}

\begin{tabular}{|c|c|}
\hline $100-300 \mathrm{PC}$ & $\begin{array}{l}\text { Presence of particles with small air } \\
\text { bubbles. } \\
\text { (This is typical after filling oil) }\end{array}$ \\
\hline Up to $500 \mathrm{PC}$ & $\begin{array}{l}\text { This level in an oil barrier space may be } \\
\text { considered as normal deterioration. } \\
\text { (This does not affect the dielectric } \\
\text { withstand level) }\end{array}$ \\
\hline$>1000 \mathrm{PC}$ & $\begin{array}{l}\text { This can be caused by different } \\
\text { degradation process } \\
\text { a. 2000-4000 PC level generally } \\
\text { signifies increasing moisture level. } \\
\text { (PD inception level is reduced in the } \\
\text { case) } \\
\text { b. } \\
\text { impregnation } \\
\text { c. }>2500 \text { pC is cellulose - will cause } \\
\text { destructive ionization if prolonged } \\
\text { d. }>10,000 \text { PC in oil- will cause } \\
\text { destructive ionization if prolonged }\end{array}$ \\
\hline
\end{tabular}

The different methods of PD detection are shown in Table VII

TABLE VII METHODS OF DETECTION OF PD

\begin{tabular}{|c|c|c|c|}
\hline No. & $\begin{array}{l}\text { Type of } \\
\text { Sensor }\end{array}$ & Advantages & Disadvantages \\
\hline 1. & $\begin{array}{l}\text { Electric } \\
\text { Direct } \\
\text { Connection } \\
\text { to the Test } \\
\text { Tap of } \\
\text { bushing or } \\
\text { through high } \\
\text { frequency CT } \\
\text { on ground } \\
\text { wires }\end{array}$ & Good Sensitivity & $\begin{array}{l}\text { Sensor installation } \\
\text { is possible only } \\
\text { when transformer is } \\
\text { de energized }\end{array}$ \\
\hline 2. & $\begin{array}{l}\text { Electromagne } \\
\text { tic Antenna }\end{array}$ & Easy to use & $\begin{array}{l}\text { High disturbance of } \\
\text { ambient }\end{array}$ \\
\hline 3. & $\begin{array}{l}\text { Acoustic } \\
\{\text { Pie } 30 \\
\text { Acceleromete } \\
r \text { placed on } \\
\text { Tank) }\end{array}$ & $\begin{array}{l}\text { - } \text { Easy to use } \\
\text { - Can detect } \\
\text { acoustic } \\
\text { Emission } \\
\text { magnitude } \\
\text { - Approximate } \\
\text { location of PP } \\
\text { can be } \\
\text { identified } \\
\end{array}$ & $\begin{array}{l}\text { Low sensitivity } \\
\text { (can detect } \\
\text { PD>10,000 PC) }\end{array}$ \\
\hline 4. & $\begin{array}{l}\text { UHF PD } \\
\text { Probes } \\
\text { (UHF } \\
\text { Couplers) }\end{array}$ & $\begin{array}{l}\text { Can be installed in } \\
\text { drain value or } \\
\text { special flanges } \\
\text { installed at factory } \\
\text { on tank. }\end{array}$ & $\begin{array}{l}\text { Less affected by } \\
\text { ambient PD as the } \\
\text { measurement is at } \\
\text { UHF }\end{array}$ \\
\hline
\end{tabular}

B. Furan Analysis and Degree of Polymerization (DP)of Transformers

When the transformer operates the insulation ages (becomes weak) and it would ultimately lead to a breakdown causing the failure of the transformer. The number of glucose rings in the cellulose is reduced when the kraft paper ages and this is called Degree of Polymerization (DP).

New Cellulose will have 1000-1200 glucose rings when a transformer is manufactured, what it is processed under drying some of the rings are broken down and hence the DP value of new transformer is about 950 .

A DP value of 250 is considered as the end point of insulation life and at this point the insulation becomes highly brittle and the tensile strength of the cellulose becomes very low. [If left without disturbance some transformers may give extended useful service after reaching this point].

Measuring the DP value of the insulation paper can be done by taking sample from the transformer. However, this has several drawbacks like

(a) The transformer will have to be switched off and opened to take a sample and

(b) The sample collected may not be from the area of maximum aging i.e. the hot spot

The disintegration of the cellulose inside the transformer generates Furan Compounds which are dissolved in the transformer oil. Hence, it is convenient to analyze the transformer oil sample for Furan content to determine the aging (DP) of the insulation. This can be done without switching off the transformer. The Furan compounds generated by various types of reactions are different. The concentration of Furaldehyde (2FAL) in the oil is due to the overheating of the paper and the maximum aging is at the location of hot spot. The drawback of this method is that the measurement gives an average of the Furan Concentration and therefore, the same at the hot spot may be much higher. The concentration of Furans is measured by High Pressure Liquid Chromatography. The concentration of various Furans indicate different types of stresses as shown in Table VIII

TABLE VIII CONCENTRATION OF FURAN WHICH INDICATES DIFFERENT TYPES OF STRESSES

\begin{tabular}{|c|c|c|c|}
\hline S1. No. & Type of Furan & Symbol & Nature of Stress \\
\hline 1 & $\begin{array}{c}5-\text { Hydroxymethyl } 2 \\
\text { Furfuraldehyde }\end{array}$ & $5 \mathrm{H}_{2} \mathrm{~F}$ & Oxidation \\
\hline 2 & Furfural Alcohol & $2 \mathrm{FOL}$ & High moisture \\
\hline 3 & 2 Furaldehyde & $2 \mathrm{FAL}$ & Overheating \\
\hline 4 & $\begin{array}{c}\text { Furyl Methyl } \\
\text { Ketone }\end{array}$ & $2 \mathrm{ACF}$ & Lightning \\
\hline 5 & $\begin{array}{c}5 \text { Methyl }-2- \\
\text { Furaldehyde }\end{array}$ & $2 \mathrm{M}_{2} \mathrm{~F}$ & $\begin{array}{c}\text { Local Severe } \\
\text { Overheating }\end{array}$ \\
\hline
\end{tabular}

The concentration of 2 FAL value is used by different authors to estimate the DP value and the results of DP values corresponding to the concentration of 2 FAL values as per "chengdong" are given in Table IX

TABLE IX CORRESPONDING TO THE CONCENTRATION OF 2FAL VALUES AS PER "CHENGDONG"

\begin{tabular}{|c|c|c|}
\hline Sl. No. & $\begin{array}{c}\text { FURAN (2 FAL) } \\
\text { PPM }\end{array}$ & Estimate DP Value \\
\hline 1 & 0.01 & 1003 \\
\hline 2 & 0.10 & 717 \\
\hline 3 & 0.50 & 517 \\
\hline 4 & 1.0 & 431 \\
\hline 5 & 2.5 & 318 \\
\hline 6 & 5 & 232 \\
\hline 7 & 10 & 146 \\
\hline 8 & 15 & 95 \\
\hline
\end{tabular}

C. Sweep Frequency Analysis (SFRA)

The transformer is a complex RLC network and any form of damage, inconsistency or deformation anywhere in the active 
part results in change of this RLC circuit. When different frequencies are applied to the transformer, the RLC network offers different impedance path and the transfer function at each frequency is a measure of the effective impedance of the network. Any geometrical change alters the RLC network which in turn changes the transfer function at different frequencies thereby highlighting the area of concern.

When a new transformer is manufactured and passes the tests, the SFRA of the transformer can be taken for using as a reference (signature). This can be compared with SFRA measurement in future, for example, after transportation to site, after installation, after an incident like a tripping, earthquake etc.

If SFRA of a transformer is not available, detection of abnormalities can be tired in any one of the following methods.

- Checking the SFRA of another transformer of the same design from the same batch of production, if available.

- Comparing SFRA of other phases of the transformer

SFRA test is done typically between $20 \mathrm{~Hz}$ to $1 \mathrm{MHz}$

The number of tests for various types of transformers is as per Table 10

TABLE X NUMBER OF TESTS FOR VARIOUS TYPES OF TRANSFORMERS

\begin{tabular}{|c|c|c|}
\hline Sl. No. & Type of Transformer & Number of Tests \\
\hline 1 & 2 Winding Transformer & 15 \\
\hline 2 & $\begin{array}{c}\text { Auto Transformer without } \\
\text { tertiary }\end{array}$ & 18 \\
\hline 3 & Auto Transformer with tertiary & 33 \\
\hline 4 & 3 Winding Transformer & 36 \\
\hline
\end{tabular}

The response of SFRA for different range of frequencies can pin-point the region / component of concern / problem. A guideline for the interpretation of probable reasons is given in Table XI.

TABLE XI GUIDELINE FOR THE INTERPRETATION OF PROBABLE

\begin{tabular}{|c|c|c|l|}
\hline $\begin{array}{c}\text { Sl. } \\
\text { No. }\end{array}$ & $\begin{array}{c}\text { Frequency } \\
\text { Range }\end{array}$ & Component & $\begin{array}{l}\text { Probable reasons } \\
\text { for deviation of } \\
\text { SFRA }\end{array}$ \\
\hline 1 & $\leq 2000 \mathrm{~Hz}$ & $\begin{array}{c}\text { Main Core } \\
\text { Main Winding } \\
\text { Inductance }\end{array}$ & $\begin{array}{l}\text { Core deformation, } \\
\text { core joints } \\
\text { becoming loose, } \\
\text { open circuit of } \\
\text { winding, shorted } \\
\text { turns, Residual } \\
\text { Magnetism }\end{array}$ \\
\hline 2 & $2 \mathrm{KHz}-20$ & $\begin{array}{l}\text { Shunt } \\
\text { Inductance } \\
\text { MHz }\end{array}$ & $\begin{array}{l}\text { Movement } \\
\text { winding and } \\
\text { clamping } \\
\text { structure } \\
\text { - Loose clamping }\end{array}$ \\
\hline 3 & $20 \mathrm{KHz}-400$ & Main Windings & $\begin{array}{l}\text { Deformation within } \\
\text { the main or tap } \\
\text { windings }\end{array}$ \\
\hline 4 & $400 \mathrm{KHz}-1$ & $\begin{array}{l}\text { Main windings } \\
\text { Tap windings } \\
\text { Internal leads }\end{array}$ & $\begin{array}{l}\text { Movement of } \\
\text { the main \& Tap } \\
\text { winding } \\
\text { Ground } \\
\text { Impedance } \\
\text { variation }\end{array}$ \\
\hline & & &
\end{tabular}

\section{B. $\quad$ Dielectric Frequency Response Analysis}

The traditional method of measuring the moisture content of the oil in the transformer does not give the oil absorbed in the cellulose insulation. This is because when the transformer is loaded, and the winding temperature rises, the moisture comes out from the cellulose and absorbs in oil. When the load comes down the temperature comes down and the moisture returns back to the cellulose. Though the moisture equilibrium curves can be used to determine the moisture in cellulose, the results are highly dependent on temperature of the oil and it may give inaccurate results.

The dielectric frequency response is an advanced technique to ascertain the insulation of moisture. The frequency response of a dielectric is a unique characteristic of a particular insulation system. The increased moisture content changes the dielectric model and the frequency response.

By measuring the dielectric response over a wide frequency range, the moisture content of the insulation can be determined and the condition assessed.

The test is normally done between the High Voltage and Low Voltage winding of a transformer by applying frequencies from $0.001 \mathrm{~Hz}$ to $1000 \mathrm{~Hz}$ to measure the dissipation factor. The voltage used for testing is up to 200 volts. The moisture content and aging is revealed at higher frequencies. The shape of the curve shows the relative moisture levels and a typical response pattern is shown in Figure-1

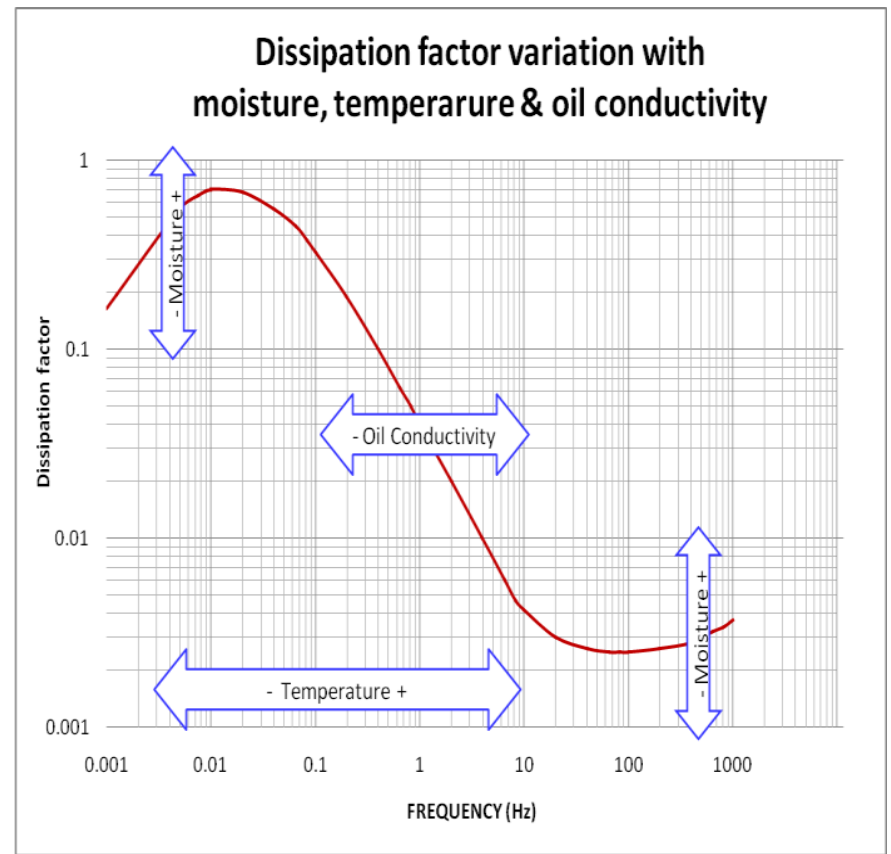

Figure I Dielectric Frequency Response Pattern

\section{Recovery Voltage Measurement (RVM)}

A step voltage is applied to the transformer and a charging current flow. Then it is short circuited during the discharge time and then it is open circuited. A recovery voltage appears across the terminals. This is caused by the unfinished polarization.

The recovery voltage is measured by changing the charging time. The discharging time is kept as 2 times charging time for all measurements. These measurements at different charging times give the polarization spectra. 


\section{Optical Spectroscopy}

The absorbance of ultra violet (UV) light of fresh oil is low. When the oil ages, the absorption of UV light goes up. The absorption is the highest between the wavelengths of 200-380 $\mathrm{nm}$. Figure 2 shows the pattern of absorbance of UV light in fresh oil and service aged oil.

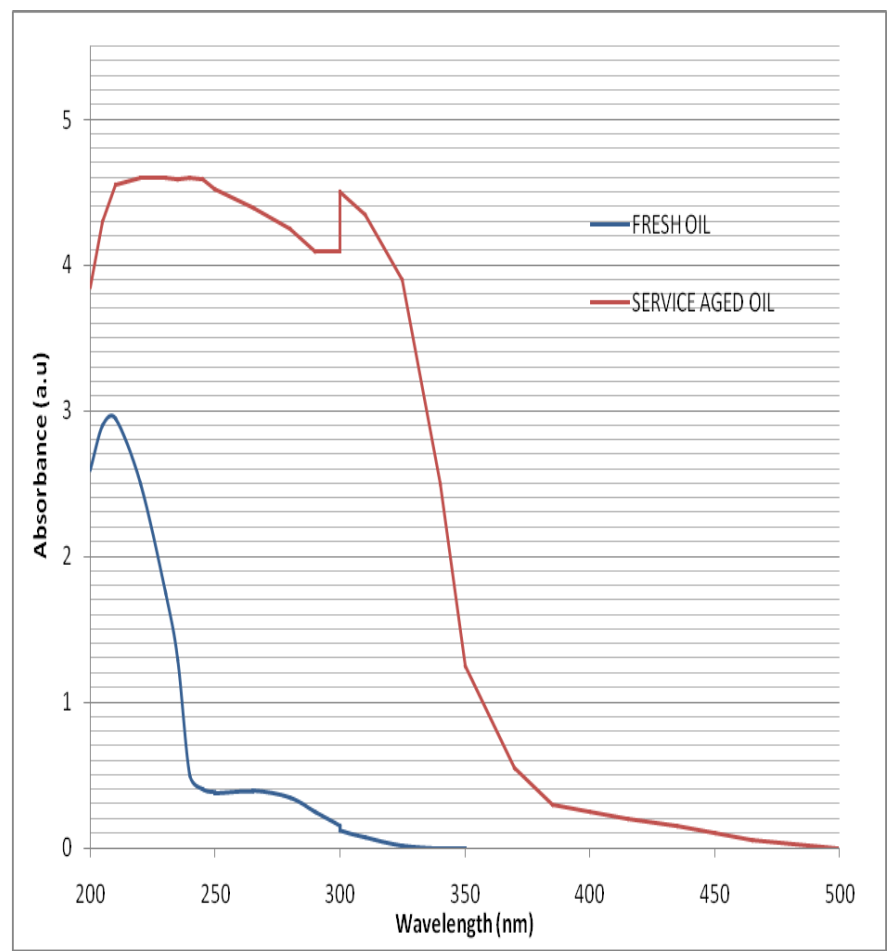

Figure II Absorbance Of Ultra Violet (Uv) Light In Fresh Oil And Aged Oil

\section{E. $\quad$ Search Coil based on-line diagnostics of transformer} internal faults

Internal faults related to transformer windings such as inter turn faults and winding displacement changes the inductance of the winding when compared to the inductance at healthy conditions. If search coils are installed during manufacture, the induced voltages in the search coils can be analyzed to monitor the changes of the inductance. The faulty winding and location of the defect can be detected.

F. $\quad$ Polarization and Depolarization Current Test (PDC) The polarization current of a transformer winding is a function of the geometry, oil properties \& aging. Initial value of polarization current is determined by the oil conductivity. The depolarization current comes down with the elapse of time when compared to polarization current depending on the moisture. A typical pattern of the polarization and depolarization current is shown in Figure 3

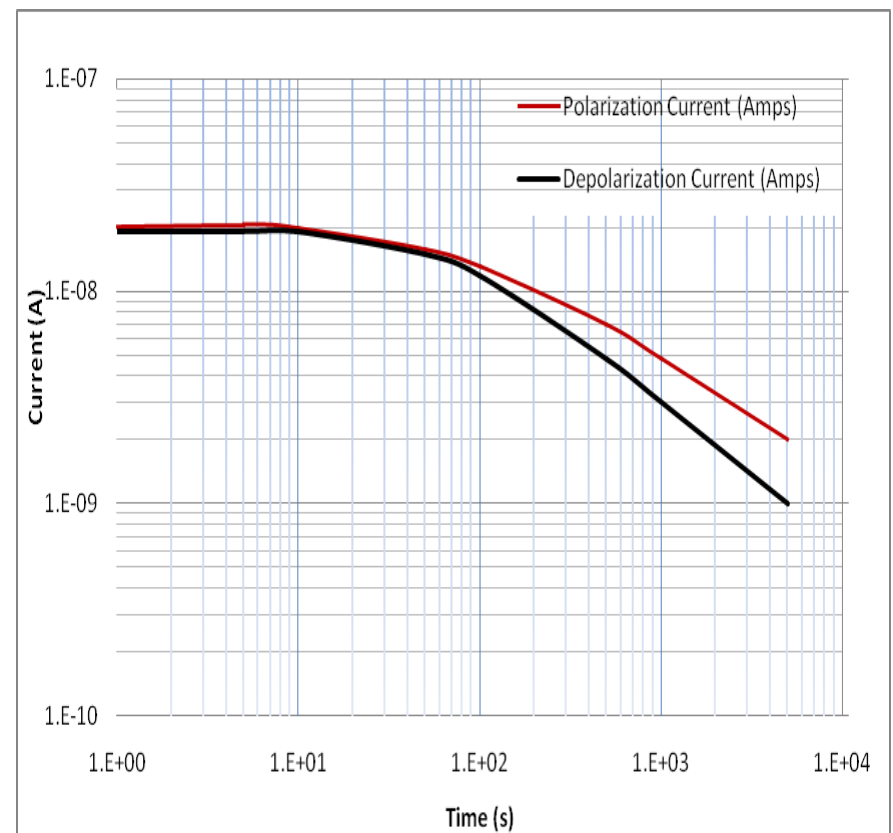

FIGURE III POLARIZATION \& DEPOLARIZATION CURRENT WITH HIGH MOISTURE IN CELLULOSE $(\approx 1 \%)$

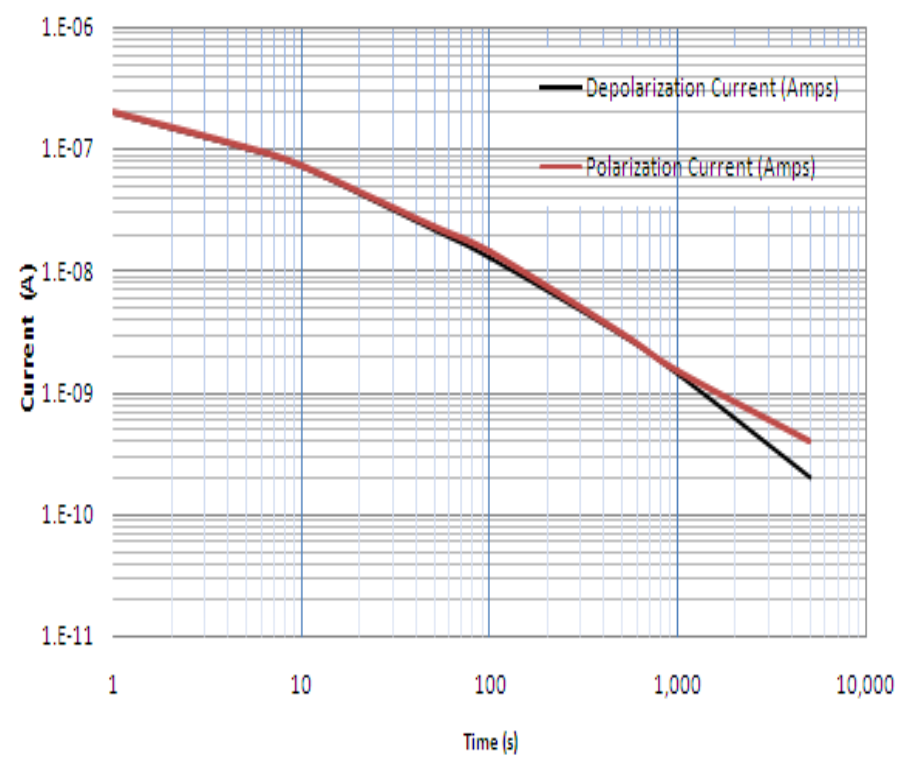

Figure IV Polarization \& Depolarization Current With High Moisture In Cellulose $(\approx 5 \%)$

\section{G. Embedded wireless monitoring and Fault diagnostic} system

On line monitoring is possible for diagnostic methods including dissolved gases in oil, oil temperature, winding temperature, oil level, core temperature, cooler operation etc. Embedded system is used and the data is transmitted by RF transmitter to the control room. Schematic diagram of a typical wireless monitoring system is shown in figure 5 


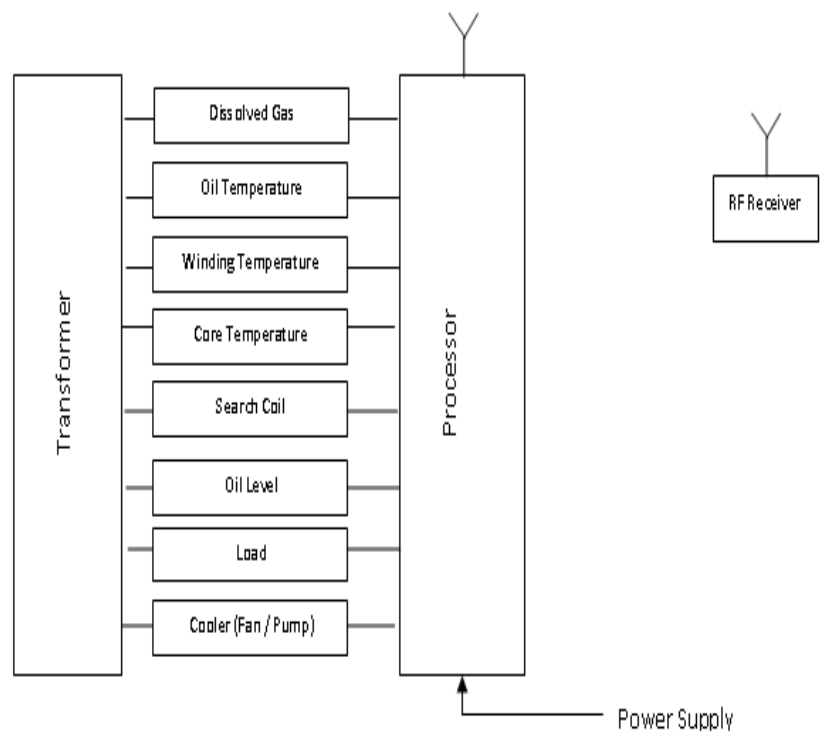

Figure V Schematic Of Embedded Wireless Monitoring System

\section{H. $\quad$ Frequency Domain Spectroscopy (FDS)}

When a dielectric material is subjected to an Electric field, the electrical dipoles are oriented in the direction of the field. This orientation has a time delay which depends on the material, the moisture content and the geometry of the insulation. The frequency range used for analysis is normally $0.001 \mathrm{~Hz}$ to $1000 \mathrm{~Hz}$.

\section{I. $\quad$ Monitoring of temperature}

Monitoring of the ambient, winding, oil and tank body temperatures can identify any excessive temperature above the permissible values. If the temperature exceeds the designed value applicable for the class of insulation, the aging becomes rapid and also this can be an indication of defects / faults leading to failure.

The top oil temperature and winding temperature can be monitored on-line and tools are available for remaining life estimation \& load management.

On-line thermograph can monitor and detect temperature gradients on tank surface. The gradients can be compared to the tested values under defined operating conditions to take suitable action.

\section{J. $\quad$ Load Monitoring}

The loads of each phase of the primary, secondary, and other windings (if applicable) is monitored for load management by including the data of ambient temperature, oil temperature and winding temperature. Where Fans and pumps are used for transformer cooling, the input currents to these devices and the operation can be monitored.

\section{K. Vibration Monitoring}

Excessive vibration is often an indication of abnormal operation of fan, pump, loose coils, loose clamping, shorted turns etc. which can lead to a failure.

For comparison, vibration measurement results of new transformer after installation is necessary.
L. Monitoring of the functioning of bushings \& on Load Tap Changer

The operation of condenser bushing is monitored by measuring the current through the test tap in operation. Change in tan delta and the charging current are monitored to detect the abnormality / fault of the bushing.

- In oil insulated on-load tap changer, (OLTC) the contact temperature can be indirectly monitored by measuring the temperature of the oil in the OLTC compartment. This temperature is compared with the oil temperature of the main tank.

\section{FUZZY INFORMATION APPROACH TO INTEGRATE RESULTS OF DIFFERENT DIAGNOSTIC METHODS}

Good experience is essential to interpret the results of many of the diagnostic techniques with accuracy. Artificial Intelligence (AI) tools can be applied to arrive at the most probable interpretation using the Fuzzy information approach. Information about the relationship between different fault types and diagnostic results is made into a fault tree.

- This approach consists of the following:

- Select the diagnostic method.

- Initiate the probability of all conclusions showing probabilities between 1 and zero

- The measurement results are then applied to the fault tree

- Perform conflict resolution

- Calculate the basic assignment for all nodes of the fault tree

- Repeat the procedure for all measurement method and aggregate the results

\section{CONCLUSION}

A review of the important monitoring and diagnostic methods used for oil filled transformers is presented in this paper. Guideline values of Dissolved gases, partial Discharge and Furan (2FAL) levels for interpretation of results are presented. The paper further presents the principles of techniques like SFRA, DFRA, RVM optical spectroscopy, PDC, Frequency Domain spectroscopy etc.

\section{REFERENCES}

[1] IEC 60076-7 Loading guide for oil immersed power transformers

[2] IEC 60076-18-20118 Transformer - part 18 measurement of frequency response

[3] IEC 60599-2007-05 Mineral Oil impregnated Electrical Equipment in service. Guide to the interpretation of Dissolved and Free gas analysis

[4] IEC 60567-2011 Guide for the sampling of gases and oil from oil filled Electrical Equipment for the analysis of free and dissolved gases

[5] IEEE/ANSI C57.143.2012 Guide for application of monitoring to liquid immersed transformers and components

[6] IEC 60270 : 2060 High voltage test techniques - partial discharge measurements

[7] IEEE/ANSI C57-149-2013 Guide for the application of frequency response analysis for oil immersed transformer

[8] IEEE/ANSI C.57.104.2008 IEEE/ANSI guide for interpretation of gases generated in oil immersed Transformer

[9] IEEE/ANSI C57.152-2013 Guide for Diagnostic Field testing of Fuild Filled Power Transformer

[10] CIGRE Technical Brochure 630 Guide on Transformer intelligent condition Monitoring System CIGRE WG A2.44.Tutorial 
[11] Ioana FĂGĂRĂȘAN , Sorina COSTINAS , Sergiu St. ILIESCU; "Monotoring and diagnostic methods for high voltage transformers"; University of Politechnica of Burcharest Bulletin series C Vol 70 No , 2008

[12] P. A. Venikar, M. S. Ballal, B. S. Umre, and H. M. Suryawanshi "Search Coil based online diagnostics of Transformer integral faults" IEEE DOI 10.1109/TPWRD 2017-2682083

[13] K. Tomsovic, M. Tapper , T. Ingvarsson; "Fussy information approach to integrating transformer diagnostic methods" IEEE - DO 10.1109/61.252690; TPD Vol 8 No 3 July 1993
[14] Abdelrahman M. Alshehawy, Diaa-Eldin A. Mansour, Mohsen Ghali, "Condition assessment of aged transformer oil using optical spectroscopy techniques"; DOI: 10.1109/CEIDP.2016.7785661 2016 IEEE Conferences on Electrical Insulation and Dielectric Phenomena (CEIDP).

[15] H. Rahbarimagham, S. Esmaeili, G. B. Gharehpetian; "Electromagnetic wave application for detection of mechanical defects in transformer windings". IEEE sensors journal Vol 17, issue 16, Aug 15, 2017 